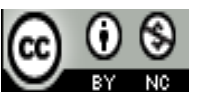

Jurnal Pendidikan IPS Indonesia is licensed under

A Creative Commons Attribution-Non Commercial 4.0 International License

\title{
Pengembangan Media Pembelajaran Terpadu Berbasis Aplikasi FrEemind dALAM MENINGKATKAN KUALITAS PEMBELAJARAN IPS DI JURUSAN PGMI FAKULTAS ILMU TARBIYAH DAN KEGURUAN UIN MAULANA MALIK IBRAHIM
}

\author{
Nur Lailatus Zahroh \\ UIN Maulana Malik Ibrahim Malang, Jawa Timur \\ E-mail: zahrafairuz12@gmail.com
}

\begin{abstract}
Penelitian ini dilatarbelakangi oleh ditemukannya permasalahan pada penelitian sebelumnya yaitu adanya model pembelajaran terpadu namun media yang digunakan masih terpisah. Oleh karena itu dibutuhkan sebuah media yang mampu memadukan semua materi IPS. Rumusan masalah difokuskan pada apakah media pembelajaran berbasis aplikasi freemind dapat meningkatkan kualitas pembelajaran IPS SD di SD di jurusan PGMI Fakultas Tarbiyah UIN Maulana Malik Ibrahim Malang. Metode yang digunakan dalam penelitian ini adalah Research \& Development Uji coba media dilakukan dengan metode eksperimen. Tiga hasil penelitian ini yaitu Media yang diproduksi adalah media pembelajaran dengan tema Indonesia klasik ini berupa media visual dari penggunaan aplikasi mindmap/freemind. Media pembelajaran berbasis aplikasi mindmap/freemind dapat meningkatkan kualitas pembelajaran IPS SD di jurusan PGMI UIN Maulana Malik Ibrahim Malang. Media pembelajaran berbasis aplikasi mindmap/freemind dapat meningkatkan pemahaman materi IPS Mahasiswa lebih tinggi dari pada media yang lain. Oleh karena itu media pembelajaran ini sebaiknya terus digunakan dalam pembelajaran IPS.
\end{abstract}

Keywords: Media Pembelajaran Terpadu Berbasis Aplikasi Freemind, Kualitas Pembelajaran IPS

\section{Pendahuluan}

Education Kualitas pembelajaran merupakan salah satu hal yang harus diperhatikan dalam meningkatkan mutu pendidikan Peraturan Pemerintah no 19 tahun 2005 menjelaskan tentang pembelajaran yang berkualitas yaitu pembelajaran yang diselenggarakan secara interaktif, inspiratif, menyenangkan, menantang memotivasi peserta didik untuk berpartisipasi aktif serta memberikan ruang yang cukup bagi prakarsa, kreativitas, dan kemampuan sesuai bakat minat dan perkembangan fisik dan psikologi peserta didik.

Kualitas pembelajaran harus terus ditingkatkan. Peningkatan kualitas pembelajaran dimaksudkan agar tercapai keunggulan dalam prose pembelajaran. Suatu pembelajaran yang unggul adalah pembelajaran yang mengutamakan hasil dan memberi peluang yang tinggi bagi guru dan peserta didik untuk aktif, inovatif, dan pemanfaatan sumber belajar yang banyak dan bagus (Warsita, 2008:263)

Salah satu cara meningkatkan kualitas pembelajaran adalah dengan menggunakan media pembelajaran. Media pembelajaran merupakan perpaduan antara bahan dan alat atau perpaduan antara soft-ware dan hardware. Adapun kualitas pembelajaran yang perlu ditingkatkan dengan media pembelajaran adalah pembelajaran IPS terpadu yang telah dikembangkan peneliti pada penelitian sebelumnya dengan nomer SP DIPA -025.04.2.423812/2016 dengan judul pengembangan model pembelajaran IPS terpadu dalam meningkatkan penguasaan konsep IPS mahasiswa PGMI fakultas ilmu tarbiyah dan keguruan UIN Maulana Malik Ibrahim Malang 


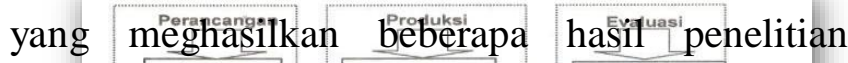
diantaranysabididalah: Persiapan
1. Model inusunan pembelajaran IPS $_{\text {Revisi }}^{\downarrow}$ terpadu dikembangkan melalui dua temạ yaitu tema Indonestakklasik dån peermasalahan injingkungan.

2. Tingkat keterterapan model pembetajaran IPS terpadu sangat bagus dilihaie ${ }^{\text {yeba }}$ danri proses pembelajaran di mana setiap langkah yang telah disusun dapat diaplikaskan dengan baik.

3. Pengaruh model pembelajaran IPS terpadu terhadap penguasaan konsep Mahasiswa masuk pada kategori menguasai $61 \%$ dan tidak mengusai 39\% untuk tema pertama dan untuk tema kedua $70 \%$ masuk pada kategori menguasai dan $30 \%$ tidak mengusai.

Akan tetapi, berdasarkan hasil wawancara dan pengamatan peneliti menemukan beberapa permasalahan diantaranya adalah:

Pertama, Waktu pembelajaran IPS SD

dengan menerapkan model pembelajaran terpadu sangat terbatas yang mengakibatkan Mahasiswa tidak mempunyai ruang untuk memahami materi lebih dalam.

Kedua, Penggunaan media yang terpisah dalam penerapan model pembelajaran IPS terpadu tahun lalu membuat pembelajaran kurang efisien. Saat pelaksanaan model pembelajaran IPS terpadu, media yang digunakan masih terpisah misalnya pada tema kedua tentang Indonesia klasik untuk konsep geografi digunakan media peta, untuk konsep sejarah digunakan media gambar dan konsep ekonomi digunakan media power point. Oleh karena itu menurut M.Husnur Ridho sebaiknya kreativitas dari pembuatan media pembelajaran dan materi lebih ditingkatkan lagi supaya lebih jelas dan menarik.

Ketiga, pada tema pertama tela dicoba media pembelajaran terpadu berupa video di mana beberapa konsep IPS dipadukan dalam satu media namun berdasarkan pengamatan bahwasannya media video belum mampu melibatkan Mahasiswa secara proaktif dalam mengintegrasikan konsep-konsep IPS sehingga Mahasiswa tidak memiliki pengalaman secara langsung dalam mengintegrasikan konsep-konsep
IPS. Hal ini tidak menyelesaikan masalah pada penelitian pertama yakni mahasiswa tampak kesulitan dan kebingungan ketika diberikan tugas untuk mengaitkan antar konsep geografi, konsep ekonomi dan konsep sejarah dalam membahas suatu tema. Mahasiswa tidak mampu memandang keadaan atau permasalahan sosial secara komprehensif dari sudut pandang ilmu sosial.

Salah satu media yang mampu mengintegrasikan berbagai konsep IPS dalam satu wadah adalah media grafis berbasis aplikasi freemind yang merupakan bagian dari program mindmap. Kelebihan dari Mindmap berbasis aplikasi freemind ini adalah dapat mempercepat pembelajaran, membantu melihat koneksi anatar topik/konsep yang berbeda, memudahkan mengingat dan meningkatkan kreativitas (Suteja, 2008:3)

Berdasarkan hasil penelitian Susilo, Rudi Salam yang berjudul Pemanfaatan Mind Map dengan aplikasi edrawmindmap.7 sebagai media inovatif dalam pembelajaran mata kuliah pengembangan pendidikan kewarganegaraan sekolah dasar bahwasannya media ini memberikan kontribusi dalam mendukung pembelajaran dan mendorong ketercapaian tujuan pembelajaran dengan perbandingan 54\% : 89\% (Susilo, Rudi Salam: 2016).

Berdasarkan latar belakang di atas maka peneliti ingin mengembangkan suatu media yang mampu memadukan beberapa konsep IPS dalam satu wadah dan memberikan pengalaman langsung kepada Mahasiswa dalam mengintegrasikan antar konsep IPS sehingga kualitas penerapan model pembelajaran IPS terpadu dapat meningkat.

\section{METODE}

Penelitian Metode yang digunakan dalam penelitian ini adalah Research \& Development. Adapun desain pengembangan dalam penelitian ini menggunakan desain pengembangan instruksional. Menurut Reigeluth dalam Suparman (2004: 30) pengembangan melalui tahap desain, produksi, dan evaluasi. Seperti pada gambar berikut: 
(Sumber: Warsita, 2008)

Adapun uji coba dilakukan dengan eskperimen kelas control dan kelas eksperimen yang diuji dengan Uji t paired dan uji $\mathrm{t}$ independence.

\section{HASIL PENELITIAN}

Setelah produk diselesaikan media di validasi oleh seorang ahli media Pembelajaran yaitu Rois Imron Rosi, M.Pd, dengan komposisi daya guna daya Tarik sengan total presentase $90 \%$.

Adapun hasil respon mahasisiwa terhadap penggunaan media, $86 \%$ Mahasiswa merasa lebih aktif dalam memahami materi IPS dengan menggunakan media aplikasi mind mapping 83.4\% Mahasiswa menganggap Media mind mapping meningkatkan kreativitas dalam belajar IPS. 82, $7 \%$ Mahasiswa menganggap Media mind mapping dapat membantu dalam mengaitkan konsep IPS yang diajarkan, dan 86.7\% Mahasiswa merasa mendapat wawasan baru tentang cara belajar IPS terpadu dengan menggunakan media aplikasi mind mapping.

84,7\% menganggap media aplikasi mind mapping bermanfaat dalam belajar IPS terpadu.

Hasil uji coba media yang membandingkan kelas control dan kelas eksperimen dengan Uji $t$ independence yaitu hasil belajar IPS menggunakan Program PPT dan Program Aplikasi Mind Mapping dengan rata-rata PPT 67.0000 dan Mind Mapping

77.5000. sehingga hasil belajar menggunakan media aplikasi mind map lebih bagus.

Pengaruh media pembelajaran terpadu berbasis aplikasi freemind terhadap pemahaman materi IPS Mahasiswa PGMI dapat dilihat dengan uji $\mathrm{T}$ test Paired. kelas eksperimen memiliki ratarata pre test 51,16 dan post test 77.50 adapun kelas kelas control. Diketahui bahwa rata-rata pre test 42,16 dan post test 67 artinya ada peningkatan hasil belajar sebelum dan sesudah menggunakan media mind map dan PPT.

Apabila di lihat dari nilai konversi 7 dengan standar nilai di UIN. Di kelas eksperimen diketahui bahwa ada perbedaan yang sangat signifikan tentang tingkat pemahaman Mahasiswa terhadap materi IPS antara sebelum dan sesudah menggunakan media aplikasi freemind. Pada kategori tidak menguasai mengalami perubahan yang sangat tinggi yaitu dari $77 \%$ menjadi $0 \%$, untuk kategori kurang menguasai dari $17 \%$ menjadi $13 \%$. Untuk kategori menguasai dari $3 \%$ menjadi $57 \%$ dan untuk kategori sangat menguasai berubah dari $3 \%$ menjadi $30 \%$. Sehingga dapat disimpulkan bahwa media aplikasi mind map fireemind sangat berpengaruh terhadap pemahaman Mahasiswa tentang materi Indonesia klasik.

Di kelas control dapat diketahui bahwa ada pada kategori saat pre test tingkat penguasaan terhadap materi IPS hanya ada dua kategori yaitu tidak menguasai sebanyak $77 \%$ dan kurang mengusai $23 \%$. Namun setelah dilakukan tindakan terjadi perubahan namun tidak signifikan karena untuk kelompok Mahasiswa yang sangat mengusai menduduki presantase yang paling kecil yaitu 17\%, kemudian $36 \%$ masuk kategori menguasai 20\% kurang menguasai dan $27 \%$ tidak menguasai dari paparan di atas dapat diketahui bahwa Media Mind Map memiliki pengaruh yang lebih tinggi terhadap penguasaan dan pemahaman materi IPS mahasiswa dari pada menggunakan ppt

\section{KESIMPULAN}

1. Curriculum Media yang diproduksi adalah media pembelajaran terpadu berbasis aplikasi mindmap/freemind dengan tema Indonesia klasik. Media berupa media visual yang merupakan hasil printout dari penggunaan aplikasi mindmap/freemind. Hasil uji coba menunjukkan bahwa media pembelajaran berbasis aplikasi mindmap/freemind dapat meningkatkan kualitas pembelajaran IPS SD 
di jurusan PGMI UIN Maulana Malik Ibrahim Malang.

2. Media pembelajaran berbasis aplikasi mindmap/freemind memiliki pengaruh terhadap pemahaman materi IPS Mahasiswa lebih tinggi dari pada media power point. Media mind map meningkatkan pemahaman Mahasiswa dengan prosentase $87 \%$ yang masuk kategori sangat menguasai dan menguasa sementara kelas control hanya 53\%. Padahal dua kategori ini memiliki prosentase yang sama yaitu $77 \%$ pada kategori tidak menguasai di tingkat pretest.

Adapun dampak penggunaan media mind map terhadap aktifitas belajar IPS Mahasiswa yang ditemukan oleh peneliti antara lain: Meningkatkan aktivitas belajar Mahasiswa, Mahasiswa mendapatkan pengalaman cara belajar IPS yang baru sehingga mereka keluar dari paradigma lama belajar IPS yaitu menghafal, Memberikan pengalaman langsung pada Mahasiswa untuk mengintegrasikan antar konsep dalam IPS. Hal ini penting untuk konsep dalam IPS. Hal ini penting untuk menjaga jati diri IPS dan karakteristik IPS

\section{DAFTAR PUSTAKA}

Ana Maria Kristina Candra. Penerapan media mind mapping untuk meningkatkan Prestasi belajar IPS kelas IV Sd Negeri purwoyoso 04 Kota Semarang dalam jurnal.fkip.uns.ac.id/index.php/snpe/arti cle/download/6987/4774 diakses tanggal 24 Oktober 2107.

Budiningsih, Asri. 2005. Belajar dan Pembelajaran. Jakarta: Rineka Cipta Indra Sungkana Nugraha. 2014. Penerapan aplikasi mind map untuk meningkatkan hasil belajar siswa. dalam repository.uksw.edu/bitstream/.../T1_70 2010032_Full\%20text.pdf. diakses tanggal 24 Oktober 2107.

Miarso, yusufhadi. 2004. Menyemai Benih

Teknologi Pendidikan. Jakarta: Prenada Media. Rusman. 2011. Model-Model

\section{Pembelajaran \\ Mengembangkan}

Profesionalisme Guru. Jakarta: rajawali Press. Rusman. 2011. Model-Model Pembelajaran Mengembangkan Profesionalisme Guru. Jakarta: rajawali Press.

Sanjaya, Wina. 2014. Media Komunikasi Pembelajaran. Jakarta: prenadamedia group.

Sopiatin, Popi. 2010. Manajemen Belajar berbasis kepuasan Siswa

Sudjana, Nana. 2010. Media Pengajaran. Bandung: Sinar Baru Algensindo 